\title{
Aqueous Agro-Industrial Waste as Corrosion Inhibitor for Stainless Steel AISI 304 in Acidic Media
}

\author{
Larissa Aparecida Corrêa Matos ${ }^{a} *{ }^{\circledR}$, Mariane Coussian Taborda ${ }^{a}$, Everson do Prado Banczek ${ }^{a}$, \\ Eliane D'Elia ${ }^{(\oplus, \text { Paulo Rogério Pinto Rodrigues }}{ }^{a}$

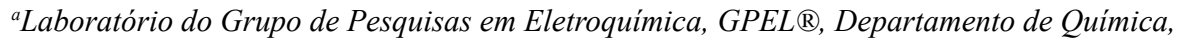 \\ Universidade Estadual do Centro-Oeste, Rua Simeão Camargo Varela de Sá, 03, CEP 85040-080, \\ Guarapuava, PR, Brasil. \\ ${ }^{b}$ Instituto de Química, Departamento de Química Inorgânica, Universidade Federal do Rio de Janeiro, \\ Cidade Universitária, CEP 21941-909, Rio de Janeiro, RJ, Brasil.
}

Received: October 29, 2018; Revised: July 1, 2019; Accepted: September 12, 2019

\begin{abstract}
The use of corrosion inhibitors is one of the most common methods to combat acid corrosion. The current studies aim to apply natural products as corrosion inhibitors, once the most used compounds are mostly toxic to the environment and to humans. The present paper purposes the application of an aqueous extract of agro-industrial waste (AEAW) to inhibit the corrosion of stainless steel AISI 304 in sulfuric acid. Gravimetric and electrochemical experiments were performed. The gravimetric experiments revealed that the extract acts as an inhibitor for stainless steel, showing inhibitory efficiency up to $81.6 \%$. The electrochemical tests show that the AEAW makes the steel surface more noble. The extract acts by adsorption in the metallic surface, following a Temkin isotherm. The results indicate that the AEAW is a promising substitute of conventional organic compounds as a corrosion inhibitor to AISI 304 stainless steel in sulfuric acid.
\end{abstract}

Keywords: Inhibition efficiency, natural inhibitor, stainless steel, acid corrosion, sustainability.

\section{Introduction}

Acid solutions, as hydrochloric acid and sulfuric acid are industrially used as cleaning solutions in different operations, as pickling, drilling and decal processes ${ }^{1,2}$. However, these solutions provide favorable conditions to the occurrence of corrosion processes in metallic equipment and structures. To prevent electrochemical corrosion on these industrial systems corrosion inhibitors are used to isolate the metals from corrosive media ${ }^{3}$.

Corrosion inhibitors decrease the reaction between metal and the corrosive media, by one of these processes: (i) blocking of the surface by adsorption of ions/molecules; (ii) increasing or decreasing the apparent activation energy of the corrosion process; (iii) decreasing of the reagent diffusion rate on the metallic surface and (iv) increasing the electric resistance on the metallic surface ${ }^{4}$.

Organic compounds containing heteroatoms as $\mathrm{O}, \mathrm{N}$ and $\mathrm{S}, \pi$ electrons, polar functional groups and heterocyclic compounds are efficient in reducing the corrosion rate due to their facility in adsorbing onto the metallic surface ${ }^{5}$. Many synthetic compounds present these properties, but they are been substituted by natural products due its high application cost and high environmental toxicity ${ }^{6}$.

Natural substances extracted from herbs, plants or spices with antioxidant properties are known as green corrosion inhibitors. These substances are extracted by simple procedures, with low cost and provide great inhibition efficiencies when added to the reactional media in the proper concentration ${ }^{7}$.
Plants, seeds, fruits and fruits peels extracts are known as good corrosion inhibitors since $1980^{8,9}$. Authors have been studying the action of extracts from different natural sources as corrosion inhibitors: Ammi visnaga seeds were extracted by distillation and the extract presented $99.3 \%$ efficiency with $300 \mathrm{ppm}$ addition to the electrolyte towards the acid corrosion of SX 316 steel $^{10}$. Chamomile, lemon grass, black cumin and beans presented characteristic of mixed inhibitors on the corrosion of stainless steel in sulfuric acid $1 \mathrm{~mol} \mathrm{~L}^{-111}$.

Extract from olive leaves was obtained with boiling water for $3 \mathrm{~h}$, and applied as corrosion inhibitor for carbon steel in $2 \mathrm{~mol} \mathrm{~L}^{-1} \mathrm{HCl}$. The extract presented 91\% efficiency and acts as a mixed inhibitor ${ }^{6}$. Aqueous extracts of orange, mango, passion fruit and cashew peels adsorb onto the carbon steel surface in $1.0 \mathrm{~mol} \mathrm{~L}^{-1} \mathrm{HCl}$, acting as corrosion inhibitors ${ }^{5}$. Coffee ground extracts prepared by decoction and infusion were used as corrosion inhibitor of carbon steel in $\mathrm{HCl}$ and acted as mixed inhibitors with cathodic predominance ${ }^{12}$.

Radish seeds aqueous extract acts as corrosion inhibitor for mild steel in sulfuric acid ${ }^{13}$. The garlic peels presents efficiency up to $98 \%$ to carbon steel in hydrochloric acid ${ }^{14}$, whereas the aqueous salvia leaves extract presents inhibition efficiency up to $96 \%$ to stainless steel 304 in the same corrosive medium ${ }^{15}$. Aqueous extract of Camellia sinensis acts as inhibitor for carbon steel in $1 \mathrm{~mol} \mathrm{~L}^{-1} \mathrm{HCl}$ reaching up to $89 \%$ inhibition efficiency ${ }^{16}$. 
The acid extract of barley agro-industrial waste was used as corrosion inhibitor for stainless steel and presented an efficiency of $97.0 \%$ in sulfuric acid ${ }^{17}$. Based on the above exposed the aim of this paper is to use the aqueous extract of agro-industrial waste (AEAW) as corrosion inhibitor of stainless steel 304 in $1.5 \mathrm{~mol} \mathrm{~L}^{-1} \mathrm{H}_{2} \mathrm{SO}_{4}$.

\section{Experimental}

\subsection{Preparation of the metallic substrates}

The stainless steel AISI 304 used in this study have elementary composition ( $\% \mathrm{w} / \mathrm{w}$ ) of $0.41 \% \mathrm{Si}, 18.49 \%$ $\mathrm{Cr}, 0.95 \% \mathrm{Mn}, 72.43 \% \mathrm{Fe}$ and $8.40 \% \mathrm{Ni}$. The samples were abraded with $\mathrm{SiC}$ sandpaper of \#320, \#400, \#600 and $\# 1200$, washed with distilled water and dried with hot air ${ }^{18}$. The samples were used in the gravimetric tests and as working electrodes in electrochemical tests.

For the scanning electron microscopy (SEM) assays, the samples also were polished with diamond paste of 9 , 6, 3 and $1 \mu \mathrm{m}$.

\subsection{Preparation of the aqueous extract (AEAW)}

The barley agro-industrial waste was collected, dried and grounded. The AEAW was prepared by dissolution of different masses of the agro-industrial waste, in heated distilled water $\left(90{ }^{\circ} \mathrm{C}\right)^{5}$. After the dissolution, the nondissolved waste was filtered and the supernatant was used for the preparation of a $1.5 \mathrm{~mol} \mathrm{~L}^{-1} \mathrm{H}_{2} \mathrm{SO}_{4}$ solution, used as corrosive media in gravimetric and electrochemical experiments.

\subsection{Raman spectroscopy}

The aqueous extract was characterized by Raman spectroscopy, in an Advantage 532® DeltaNu spectrometer, excited in $532 \mathrm{~nm}$ and with $8 \mathrm{~cm}^{-1}$ of resolution.

\section{Gravimetric tests}

Gravimetric experiments consisted on the immersion of stainless steel in $1.5 \mathrm{~mol} \mathrm{~L}^{-1} \mathrm{H}_{2} \mathrm{SO}_{4}$ solutions, in presence and absence of different AEAW concentrations, for $2 \mathrm{~h}$, at controlled temperature of $22 \pm 0.2^{\circ} \mathrm{C}$ in a TECNAL TE-2005 thermostatic bath.

The samples area was registered before the immersion, with a calibrated pachymeter. The mass of the samples was registered before and after $2 \mathrm{~h}$ immersion, in an analytical balance with $0.1 \mathrm{mg}$ precision. The corrosion rate $\left(\mathrm{v}_{\text {corr }}\right)$ was calculated according to the equation $1^{19}$ :

$$
v_{\text {corr }}=\frac{\Delta m}{A . t}
$$

Where $\Delta \mathrm{m}=$ mass difference before and after the experiment, in $\mathrm{mg}$; $\mathrm{t}=$ time, in hours; and $\mathrm{A}=$ metallic sample area, in $\mathrm{cm}^{2}$.
The inhibition efficiency (IE), was calculated according to equation $2^{19}$ :

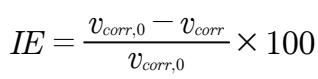

Where $\mathrm{v}_{\text {corr }, 0}$ is the corrosion rate in the absence of AEAW and $\mathrm{v}_{\text {corr }}$ is the corrosion rate in the presence of AEAW.

\subsection{Temperature effect}

The temperature effect was studied only by gravimetric tests with temperature variation in thermostatic bath, in the temperatures of: $32 \pm 0.2 ; 42 \pm 0.2$ and $52 \pm 0.2{ }^{\circ} \mathrm{C}$ for 2 $\mathrm{h}$ of immersion.

\subsection{Morphology of the metallic surface evaluation}

SEM evaluated the metallic surface morphology. The images were obtained in a TESCAN VEGA3 electronic microscope, with the application of $20 \mathrm{keV}$.

Coupled with the microscope, an energy dispersive spectrometer (EDS) Oxford X-act analyzed the elementary composition of the metallic samples, before and after immersion in corrosive media. The spectra were also obtained with the application of $20 \mathrm{keV}$.

\subsection{Electrochemical tests}

The electrochemical experiments were performed in an AUTOLAB PGSTAT302N potentiostat, in a three-electrode cell. Samples of stainless steel AISI 304 were used as the working electrode. A platinum wire with large area was used as the counter electrode and a mercurous sulphate electrode (MSE) was used as reference electrode. The electrolyte consisted of $\mathrm{H}_{2} \mathrm{SO}_{4}$ solutions, obtained with distilled water without and with different concentrations of the AEAW.

The electrochemical tests performed were open circuit potential (OCP), electrochemical impedance spectroscopy (EIS) and potentiodynamic polarization (PP), as follows:

OCP: the potential was monitored until stabilization, at approximately $2 \mathrm{~h}$ of immersion.

EIS: the measurements were realized at stable OCP with a potential perturbation of $\pm 10 \mathrm{mV}$, with 10 points per decade, in a frequency range of $10 \mathrm{kHz}$ to $0.01 \mathrm{~Hz}$.

PP: the measurements consisted of potential perturbation of $-1000 \mathrm{mV}$ until $+1800 \mathrm{mV}$ from OCP, with a scanning rate of $1 \mathrm{mV} \mathrm{s}^{-1}$.

The tests were realized three times, and the average of the assays were considered in results.

\section{Results and Discussion}

\subsection{Raman spectroscopy}

Figure 1 shows the Raman spectroscopy of the aqueous extract. The spectra obtained features three principal bands. 


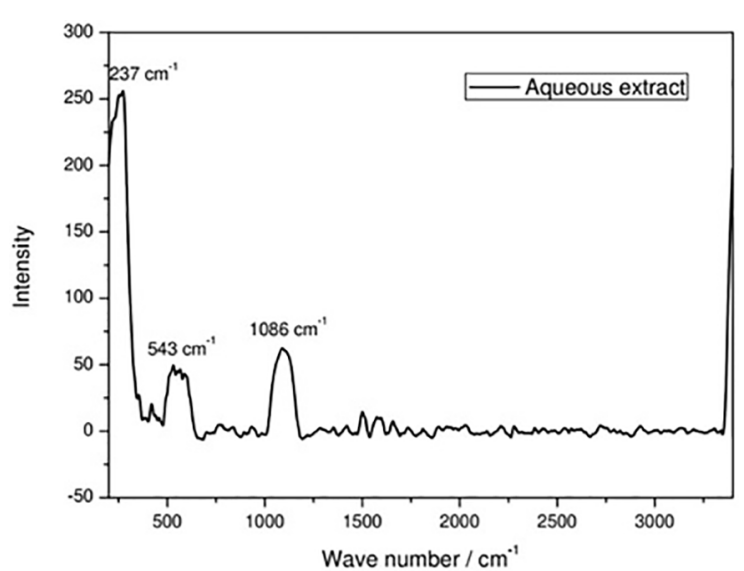

Figure 1. Raman spectra of the AEAW.

The first, which appears at $237 \mathrm{~cm}^{-1}$ is attributed to $\mathrm{C}-\mathrm{H}$ deformation; the second, at $543 \mathrm{~cm}^{-1}$, the band is related to $\mathrm{CH}_{2}$ balance and vibration; the third band, at $1086 \mathrm{~cm}^{-1}$ is due to $\mathrm{C}-\mathrm{C}$ stretch and $\mathrm{CH}_{3}$ balance ${ }^{20}$. These bands can be related to organic compounds preserved in acidic media, whose can adsorb onto the metallic surface, providing the inhibition of corrosive processes.

\subsection{Gravimetric experiments}

Table 1 shows that the corrosion rate decreased with the addition of AEAW, indicating that the extract acts promoting a partial blocking of the metallic surface. The adsorption of the extract compounds retards the rate of the corrosion processes. The inhibition efficiency (IE) increase with the increase of the extract concentration, showing 26.2 to $81.6 \%$ for extract concentration range from 1 to $5 \mathrm{~g} \mathrm{~L}^{-1}$, suggesting a dependence of the inhibition process with the amount of inhibitory species in solution ${ }^{1,6,21}$.

Table 1. Corrosion rate and inhibitory efficiency to stainless steel AISI 304 in $\mathrm{H}_{2} \mathrm{SO}_{4} 1.5 \mathrm{~mol} \mathrm{~L}^{-1}$ in presence and absence of AEAW.

\begin{tabular}{ccc}
\hline [EAqRA] $/ \mathrm{g} \mathrm{L}^{-1}$ & vcorr $/ \mathrm{mg} \mathrm{cm}^{-2} \mathrm{~h}^{-1}$ & $\mathrm{IE} / \%$ \\
\hline 0 & 0.9165 & - \\
1 & 0.6762 & 26.2 \\
2 & 0.4578 & 50.0 \\
3 & 0.3554 & 61.2 \\
4 & 0.2172 & 76.3 \\
5 & 0.1685 & 81.6 \\
\hline
\end{tabular}

The inhibitory effect of the extract can be attributed to different organic compounds present in the extract, including carboxylic acids, vitamins, phenolic compounds, macromolecules as proteins that have the capability of adsorption onto the metallic surface ${ }^{22,23}$. Synergistic effects of this mixture of chemical compounds could be expected, resulting in high inhibition efficiencies, as observed on Table 1 , where the maximum concentration promoted an inhibitory efficiency of $81.6 \%{ }^{11}$.

\subsection{Determination of the adsorption model}

The decrease on the corrosion rate with the addition of extract indicates that the organic compounds of the aqueous extract adsorb onto the metallic surface. For organic molecules, the Bockris-Devanathan-Müller theory considers that a substitution reaction takes place on the adsorption process, where organic molecules present on solution $\left(\mathrm{Org}_{(\mathrm{ads})}\right)$ substitute the water molecules adsorbed on the metallic surface $\left(\mathrm{H}_{2} \mathrm{O}_{(\text {ads })}\right)$ :

$$
\mathrm{Org}(\mathrm{sol})+x \mathrm{H}_{2} \mathrm{O}(a d s) \rightarrow \mathrm{Org}(a d s)+x \mathrm{H}_{2} \mathrm{O}(\mathrm{sol})
$$

Where $\mathrm{x}$ is the number of water molecules substituted by one organic molecule that adsorbs onto the metallic surface $e^{24,25}$.

Different forms of interaction of the organic molecules with the metal can be responsible for the adsorption process: (a) electrostatic interactions between the surface and the organic molecules; (b) interaction between available electron pairs on heteroatoms of the inhibitory molecules and the metal; (c) interaction between $\pi$ electrons with the metal or even a combination of the forms presented in (a)-(c). The extract molecules adsorption mechanism can be explained by different isotherm models, presented on equations $3-8^{25}$ :

$$
\begin{gathered}
\text { Langmuir: } \frac{c}{\theta}=\frac{1}{K}+c \\
\text { Freundlich: } \log \theta=\log K+\frac{1}{n} \log c \\
\text { Temkin: } \theta=\left(-\frac{2.303}{2 a}\right) \log K+\left(-\frac{2.303}{2 a}\right) \log c \\
\text { Flory - Huggins: } \log \left(\frac{\theta}{c}\right)=\log K+\mathrm{x} \log (1-\theta) \\
\text { El-Awady: } \log \left(\frac{\theta}{1-\theta}\right)=\log K+y \log c \\
\text { Frumkin: } \log \left(\frac{\theta}{c(1-\theta)}\right)=\log K+a \theta
\end{gathered}
$$

Where $\mathrm{c}$ is the extract concentration; $\theta$ is the coverage degree of the metallic surface, obtained by $\theta=\mathrm{IE} / 100 \mathrm{~K}$ is the adsorption constant of the process. $1 / \mathrm{n}$ is the Freundlich exponent; $a$ is the molecules' lateral interaction factor; $x$ is the number of water molecules substituted by a single inhibitor molecule and $y$ is the number of inhibitor molecules adsorbed in a given active site.

The isotherm models presented on equations 3-8 were applied for the AEAW, according to the inhibition efficiency data presented on Table 1. The data adjust is resumed on Table 2 .

All isotherm models admitted determination coefficients $\left(\mathrm{R}^{2}\right)$ higher than 0.9 . On literature, correlation coefficients (R) between 0.60 and 0.99 are accepted to the models description $^{12,14,24,25}$. The acid extract of agro-industrial waste followed the Langmuir mode ${ }^{17}$. The Temkin isotherm model obtained the best determination coefficient for AEAW $\left(\mathrm{R}^{2}=0.9909\right)$. 
Table 2. Adsorption parameters obtained with the AEAW on the corrosion inhibition of stainless steel in $\mathrm{H}_{2} \mathrm{SO}_{4} 1.5 \mathrm{~mol} \mathrm{~L}^{-1}$.

\begin{tabular}{ccc}
\hline Isotherm & $\mathrm{R}^{2}$ & $\mathrm{y}=\mathrm{a}+\mathrm{bx}$ \\
\hline Langmuir & 0.9491 & $\mathrm{y}=3.05+0.586 \mathrm{x}$ \\
Freundlich & 0.9716 & $\mathrm{y}=-0.555+0.710 \mathrm{x}$ \\
Temkin & 0.9909 & $\mathrm{y}=0.257+0.801 \mathrm{x}$ \\
Flory-Huggins & 0.9110 & $\mathrm{y}=-0.527+0.337 \mathrm{x}$ \\
El-Awady & 0.9851 & $\mathrm{y}=-0.470+1.56 \mathrm{x}$ \\
Frumkin & 0.9098 & $\mathrm{y}=-0.668+0.747 \mathrm{x}$ \\
\hline
\end{tabular}

This model admit that the heat of adsorption of the molecules that cover the metallic surface linearly decrease in function of the coverage, due to interactions between the adsorbed molecules. Positive values of a indicate attractive forces, whereas a negative values indicate repulsion between the molecules. Data shown in Table 2 indicate that the extract acts by repulsive forces. The aqueous extracts of Phyllantus amarus and the radish seeds extracts also acted by Temkin isotherms ${ }^{13,25,26}$. The results indicate that the extraction method changes the extract chemical composition and, consequently, the adsorption mechanism ${ }^{17}$.

Freundlich and El-Awady models presented high $\mathrm{R}^{2}$ values (0.9710 and 0.9851 , respectively), which suggests a deviation of the Temkin behavior ${ }^{27}$. The Freundlich model consider that the superficial energies are heterogeneous during the adsorption process. The $1 / \mathrm{n}$ value varies from zero to one. Exponents close to zero define a heterogeneous surface. The value observed to the AEAW was 0.71 , suggesting a predominantly homogeneous surface ${ }^{28}$. El-Awady consider the number of inhibitor molecules adsorbed in a given active site. $\mathrm{Y}<1$ show that a single molecule involved in the adsorption process has been adsorbed on more than one active site. Values of $1 / y<$ 1 suggest multilayer adsorption. The AEAW presented 1.56 for Y, which suggests a multilayer adsorption ${ }^{25}$.

Isotherm adsorption study suggests that various AEAW organic molecules adsorb onto the metallic surface, on a homogeneous form, and that repulsive force takes place between these molecules in a multilayer adsorption.

\subsection{Temperature effect}

Table 3 shows that the corrosion rate increases both in the absence $\left(\mathrm{v}_{\text {corr, } 0}\right)$ and in the presence of $5 \mathrm{~g} \mathrm{~L}^{-1}$ of AEAW $\left(\mathrm{v}_{\text {corr, } 5}\right)$ as the temperature increases, with greater increase in the presence of the extract. Consequently, the inhibition efficiency decreased with the temperature, going from $81.6 \%$ to $57.6 \%$. These results can be attributed to the physical adsorption of the extract components, that form a barrier between the metal and the corrosive media, inhibiting the stainless steel dissolution ${ }^{29,30}$.
Table 3. Temperature effect on the corrosion rate and on the inhibition efficiency of AEAW on the stainless steel surface in $\mathrm{H}_{2} \mathrm{SO}_{4}$.

\begin{tabular}{cccc}
\hline $\mathrm{T} /{ }^{\circ} \mathrm{C}$ & $\mathrm{v}_{\text {corr }, 0} / \mathrm{mg} \mathrm{cm}^{-2} \mathrm{~h}^{-1}$ & $\mathrm{v}_{\text {corr }, 5} / \mathrm{mg} \mathrm{cm}^{-2} \mathrm{~h}^{-1}$ & $\mathrm{IE} / \%$ \\
\hline 22 & 0.9166 & 0.1685 & 81.6 \\
32 & 1.535 & 0.5597 & 63.5 \\
42 & 2.338 & 0.9145 & 60.9 \\
52 & 4.442 & 1.883 & 57.6 \\
\hline
\end{tabular}

The apparent activation energy of the corrosion process can be calculated from the gravimetric experiments with temperature variation, by $\ln \mathrm{v}_{\text {corr }} v s .1 / \mathrm{T}$ plot, according to Arrhenius equation $9^{14}$ :

$$
\ln v_{\text {corr }}=\ln A-\frac{E_{a}}{R T}
$$

Arrhenius plot obtained from the experimental data is presented in Figure 2.

The plot leads to an Ea value of $41.00 \mathrm{~kJ} \mathrm{~mol}^{-1}$ for the blank and $62.01 \mathrm{~kJ} \mathrm{~mol}^{-1}$ for the inhibited solution. Similar results were found to the acid extract of agro-industrial waste and the increase of the apparent activation energy suggests that the extract components adsorption is physical, by nature ${ }^{12,17}$.

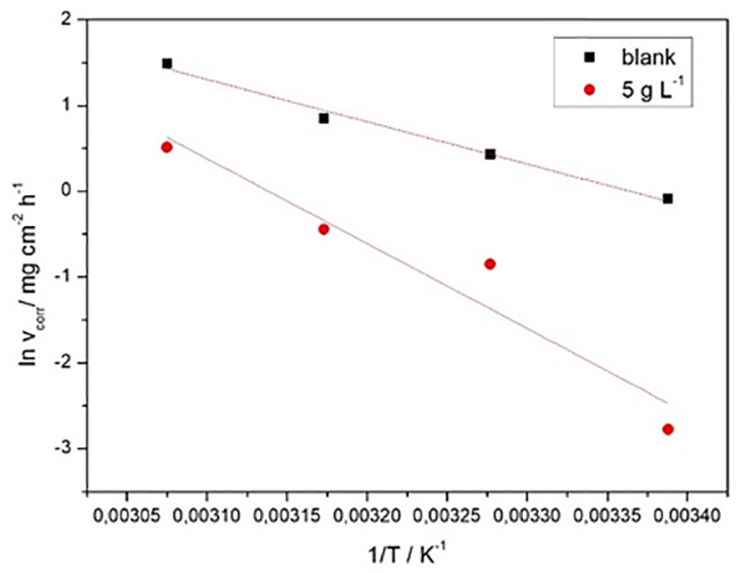

Figure 2. Arrhenius plot for AISI 304 stainless steel in $\mathrm{H}_{2} \mathrm{SO}_{4}$, in presence and absence of AEAW.

\subsection{Metallic surface morphology analysis}

SEM images are presented in Figure 3. Before immersion (Figure 3A), the surface presents only slots resulting from the preparation process. After immersion in $\mathrm{H}_{2} \mathrm{SO}_{4}$ for 2 h, Figure 3B, the sample presents heterogeneities, with evidence of development of polyhedral grains, characteristic of austenitic metals and corrosive process caused by acidic media $^{31}$. 


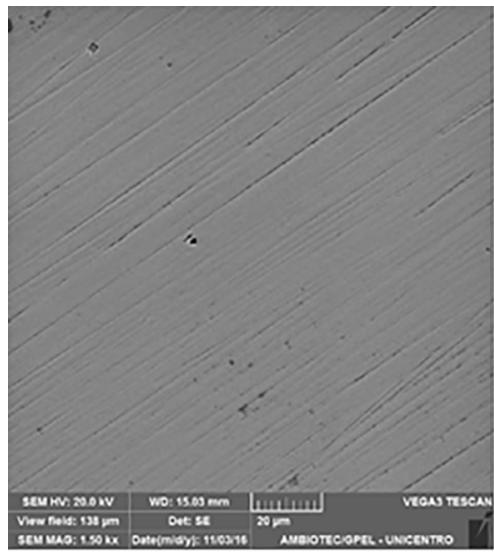

A

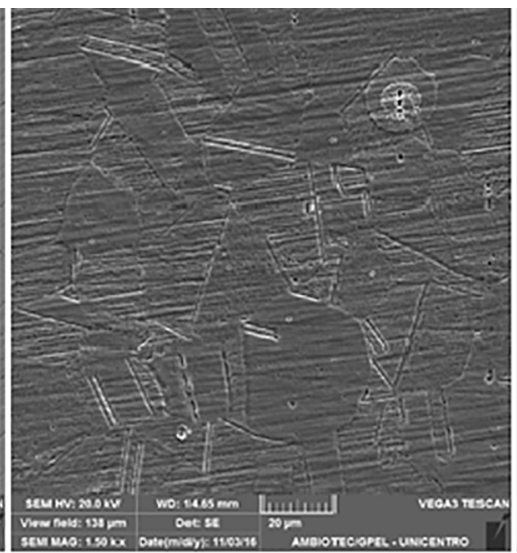

B

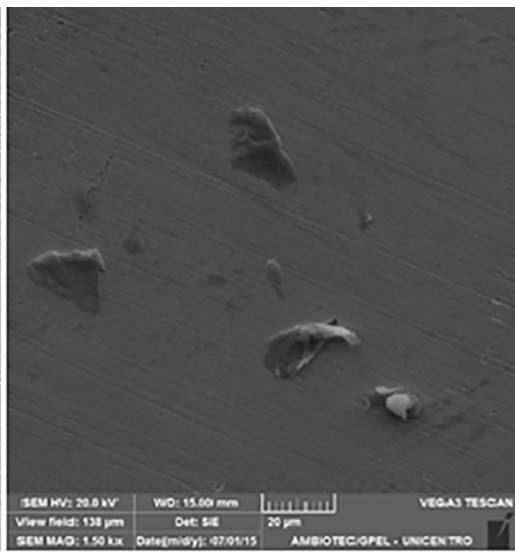

C

Figure 3. SEM images for AISI 304 stainless steel. (A) without immersion; (B) after immersion in $1.5 \mathrm{~mol} \mathrm{~L}^{-1} \mathrm{H}_{2} \mathrm{SO}_{4}$ for $2 \mathrm{~h}$; (C) after immersion in $1.5 \mathrm{~mol} \mathrm{~L}^{-1} \mathrm{H}_{2} \mathrm{SO}_{4}$ in presence of $5 \mathrm{~g} \mathrm{~L}^{-1} \mathrm{AEAW}$ for $2 \mathrm{~h} .1500 \mathrm{x}$ increase.

Figure $3 \mathrm{C}$ shows the surface of stainless steel after immersion in $\mathrm{H}_{2} \mathrm{SO}_{4}$ containing AEAW. The surface is less rough, with evidences of possibly organic material deposition, suggesting the adsorption of the extracts compounds onto the metallic surface, confirming the gravimetric results. The EDS results are shown on Table 4.

It is noted from data shown in Table 4 that the principal constituent of the metal are more available on the sample immersed in $\mathrm{H}_{2} \mathrm{SO}_{4}$, due to the oxides formation, evidencing the severe corrosive process, which was subjected. According to the addition of AEAW, the availability of these elements decrease, showing the inhibition of the process. Besides, the increase of the availability of carbon on the metallic surface indicates the adsorption of organic compounds, that corroborates with the other experimental data ${ }^{32}$.

\subsection{Electrochemical experiments}

The OCP results are presented in Figure 4. $\mathrm{In}_{2} \mathrm{SO}_{4}$ solution, the stainless steel potential shows a displacement to more negative values in the first seconds with a subsequent increase of the potential until its stabilization. This indicates that the steel surface is more active in the first seconds of immersion and that the immersion changes the superficial oxides characteristics, making it more protective ${ }^{32}$.

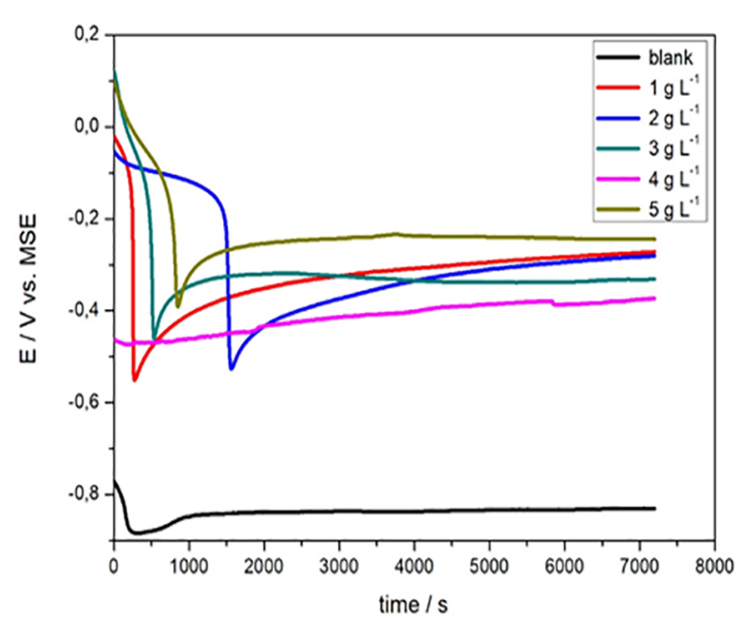

Figure 4. OCP plots for AISI 304 stainless steel in $\mathrm{H} 2 \mathrm{SO} 4$, in presence and absence of AEAW.

The same behavior is observed for the samples where AEAW was added. In all cases, it is observed that the OCP was significantly displaced to more positive values, indicating that the extract makes the oxide more protective, involving interaction of the organic molecules from the extract with the oxide ${ }^{17}$.

Table 4. Elementary composition of AISI 304 stainless steel samples after immersion in $\mathrm{H}_{2} \mathrm{SO}_{4}$, in presence and absence of AEAW, obtained by EDS.

\begin{tabular}{cccc}
\hline Element & \multicolumn{1}{c}{ / $/ \mathrm{w}$} & \\
\cline { 2 - 4 } & Without immersion & $1.5 \mathrm{~mol} \mathrm{~L}^{-1} \mathrm{H}_{2} \mathrm{SO}_{4}$ & $5 \mathrm{~g} \mathrm{~L}^{-1} \mathrm{AEAW}$ \\
\hline $\mathrm{C}$ & 1.98 & 3.33 & 6.25 \\
$\mathrm{Si}$ & 0.353 & 0.365 & 0.36 \\
$\mathrm{Cr}$ & 15.5 & 16.0 & 15.4 \\
$\mathrm{Mn}$ & 1.01 & 1.03 & 0.895 \\
$\mathrm{Fe}$ & 56.8 & 58.1 & 55.9 \\
$\mathrm{Ni}$ & 6.21 & 6.36 & 6.17 \\
\hline
\end{tabular}


The polarization potentiodynamic results are presented in Figure 5. The polarization curves show that the cathodic reactions occur in potentials between $-1500 \mathrm{mV} / \mathrm{MSE}$ until $-800 \mathrm{mV} / \mathrm{MSE}$. On this interval, $\mathrm{H}_{2(\mathrm{~g})}$ is formed ${ }^{32}$. From approximately $-800 \mathrm{mV} / \mathrm{MSE}$, the metallic oxidation takes part, representing the anodic interval of the curve.

Region between $-800 \mathrm{mV} / \mathrm{MSE}$ and $-500 \mathrm{mV} / \mathrm{MSE}$ corresponds to the first anodic peak, concerning to the formation of chromium, nickel and iron oxides. Interval between $-500 \mathrm{mV} / \mathrm{MSE}$ and -250 $\mathrm{mV} / \mathrm{MSE}$ corresponds to the second anodic peak, regarding the reactions of superficial oxides of higher valence. Between -250 mV/MSE and 500 $\mathrm{mV} / \mathrm{MSE}$ is the passive region, where there is no change on the $\mathrm{j}$, due to the occurrence of reactions of increase of the thickness of the oxides film formed on the active regions. From $500 \mathrm{mV} / \mathrm{MSE}$ the steel dissolution starts, where the passive film reacts forming soluble species. After $1250 \mathrm{mV} /$ MSE the reactions with chromium oxides start, in a region known as transpassivation region ${ }^{32,33}$.

With the addition of AEAW, there was a reduction of the current density on the cathodic region, indicating that the extract acts as a cathodic inhibitor. There was a displacement of potentials to more positive values, property of a more protected surface due to the addition of AEAW.

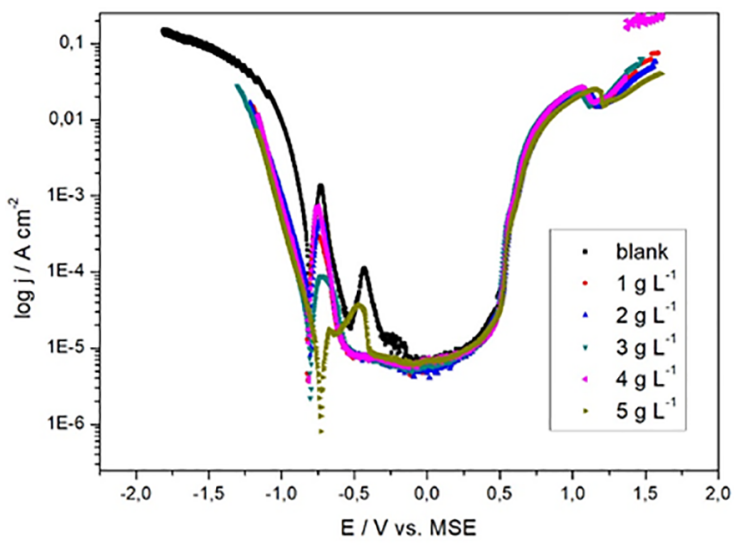

A
From Tafel extrapolation, performed on the linear region of the curves, the other electrochemical parameters were obtained and are shown in Table 5.

Comparisons of $\mathrm{E}_{\text {corr }}$ and OCP values are useful to the classification of the inhibitor, even though the distinct nature of the experiments. Literature presents that differences of potential higher than $85 \mathrm{mV}$ can classify the inhibitors as cathodic or anodic one ${ }^{15,24,29}$. Results presented in Figure 4 and in Table 5 indicate that the OCP values had a great displacement for more positive values, until $+587 \mathrm{mV}$ for 5 $\mathrm{g} \mathrm{L}^{-1}$ of AEAW, suggesting that in open circuit conditions the extract acts preferably on the anodic dissolution reaction. In the $\mathrm{E}_{\text {corr }}$ case, the displacement is of $13 \mathrm{mV}$ for $5 \mathrm{~g} \mathrm{~L}^{-1}$ of extract, suggesting that the extract acts as a mixed type inhibitor for stainless steel. The decrease of the potential displacement on the polarized electrode suggests that the extract adsorption on the metallic surface may have been affected with the application of cathodic overpotentials ${ }^{3,25}$. It is important to note that the polarization curves were performed from $-1000 \mathrm{mV}$ to $+1800 \mathrm{mV}$ vs. MSE. Anodic Tafel coefficient ( $\beta$ a) decreased with the increase of the AEAW concentration, according to the results presented on Table 5 which suggests that in higher extract concentration a modification of the anodic dissolution process could be considered ${ }^{28}$.

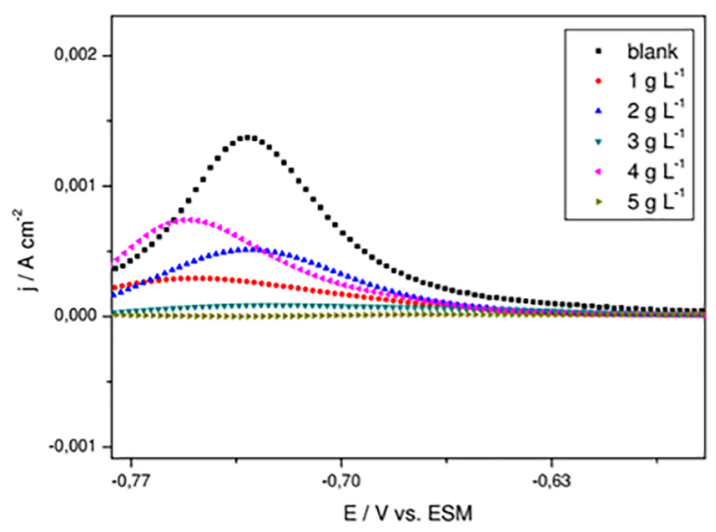

B

Figure 5. (A) Polarization curves for stainless steel in $\mathrm{H}_{2} \mathrm{SO}_{4}$ solution, in presence and absence of AEAW, $1 \mathrm{mV} \mathrm{s}^{-1}$ scanning rate; (B) Zoom of the active region.

Table 5. Electrochemical parameters obtained from polarization curves to stainless steel AISI 304 in $\mathrm{H}_{2} \mathrm{SO}_{4}$ in presence and absence of AEAW.

\begin{tabular}{lcccccc}
\hline Electrochemical parameters & \multicolumn{3}{c}{ [AEAW] } \\
\cline { 2 - 7 } & $0 \mathrm{~g} \mathrm{~L}^{-1}$ & $1 \mathrm{~g} \mathrm{~L}^{-1}$ & $2 \mathrm{~g} \mathrm{~L}^{-1}$ & $3 \mathrm{~g} \mathrm{~L}^{-1}$ & $4 \mathrm{~g} \mathrm{~L}^{-1}$ & $5 \mathrm{~g} \mathrm{~L}^{-1}$ \\
\hline $\mathrm{OCP} / \mathrm{mV}$ & -830 & -272 & -280 & -331 & -373 & -243 \\
$\beta \mathrm{a} / \mathrm{mV} \mathrm{dec}^{-1}$ & 65 & 63 & 70 & 59 & 38 & 26 \\
$-\beta \mathrm{c} / \mathrm{mV} \mathrm{dec}^{-1}$ & 123 & 145 & 148 & 148 & 141 & 139 \\
$\mathrm{E}_{\text {corr,calc }} / \mathrm{mV}$ & -787 & -814 & -810 & -787 & -814 & -818 \\
$\mathrm{E}_{\text {corr, obs }} / \mathrm{mV}$ & -807 & -820 & -800 & -799 & -812 & -820 \\
$\mathrm{j}_{\text {corr }} / \mu \mathrm{A} \mathrm{cm}-2$ & 229 & 50.4 & 55.5 & 27.1 & 36.8 & 33.1 \\
${\mathrm{Corrosion} \mathrm{rate} / \mathrm{mm}^{-2} \text { year }}^{-1}$ & 2.52 & 0.557 & 0.612 & 0.214 & 0.406 & 0.261 \\
$\mathrm{R}_{\mathrm{p}} / \mathrm{k} \Omega$ & 85.4 & 402.1 & 393.6 & 1000 & 374.5 & 428.5 \\
$\mathrm{IE} / \%$ & - & 77.9 & 75.7 & 88.1 & 83.9 & 85.5 \\
\hline
\end{tabular}


The cathodic Tafel coefficient $(\beta \mathrm{c})$ presented a slight decrease with the extract addition, and this coefficient remains almost constant with the increase of the extract concentration, indicating that the extract does not act on the $\mathrm{H}_{2(\mathrm{~g})}$ reaction ${ }^{34}$.

There was a decrease of both $\mathrm{j}_{\text {corr }}$ and corrosion rate, indicating that the AEAW acts as inhibitor in the studied conditions (at open circuit potential and at overpotential). The increase of the polarization resistance $\left(\mathrm{R}_{\mathrm{p}}\right)$ also indicates a higher resistance to the oxidation process. These results suggest that the extract acts as an inhibitor. The inhibition efficiency calculated using $\mathrm{j}_{\text {corr }}$ varied from 77.9 to $85.5 \%$ for extract concentration from 1 to $5 \mathrm{~g} \mathrm{~L}^{-1}$. The adsorption of the extract organic molecules onto the metallic surface depends on the applied potential and this behavior could explain the different IE values presented in Tables 1 and 5. On the polarized electrode, the IE reaches its maximum in 3 $\mathrm{g} \mathrm{L}^{-1}$. This is due to the potentiodynamic technique applied. On table 1, the results obtained uses a potentistatic method.

The EIS results are presented in Figure 6 and Figure 7. It is observed the presence of two capacitive loops for stainless steel in $\mathrm{H}_{2} \mathrm{SO}_{4}$. The first loop, in higher frequencies is attributed to the charge transfer and double layer capacitance, whereas the second loop is attributed to the relaxation of adsorbed intermediates onto the metallic surface ${ }^{17}$. With the addition of AEAW there is an increase of the capacitive loop diameter and the second loop is substituted by an inductive loop as the increase of extract concentration. The inductive loop presence in higher concentrations agrees with the polarization results, where the anodic Tafel coefficients present more significant changes in higher concentrations.

The double layer capacitance values $\left(\mathrm{C}_{\mathrm{d} 1}\right)$ can be obtained by Nyquist plot, according to equation 10 :

$$
C_{d l}=\frac{1}{R_{c t} 2 \pi f_{\max }}
$$

Where $f_{\max }$ is the frequency where imaginary impedance reaches its maximum on Nyquist plot and $\mathrm{R}_{\mathrm{ct}}$ is the charge transfer resistance, obtained by the diameter of the first capacitive loop. The electrochemical parameters obtained by Nyquist plots are shown in Table 6 .

Data shown in Table 6 indicate that there is an increase of $R_{c t}$ with the extract concentration with a slight decrease of the $\mathrm{f}_{\text {max }}$ value and, consequently, lower values of $\mathrm{C}_{\mathrm{dl}}$ are observed in the presence of the extract.

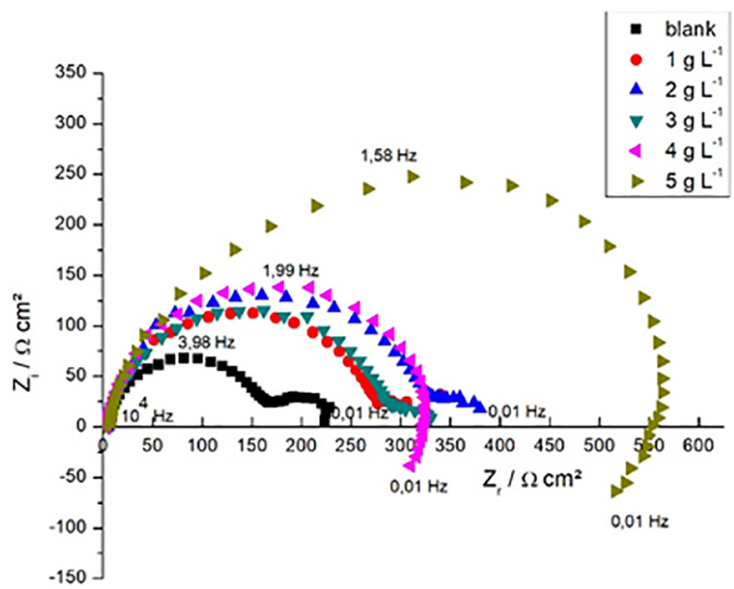

Figure 6. Nyquist diagrams for AISI 304 stainless steel in $\mathrm{H}_{2} \mathrm{SO}_{4}$ in presence and absence of AEAW.

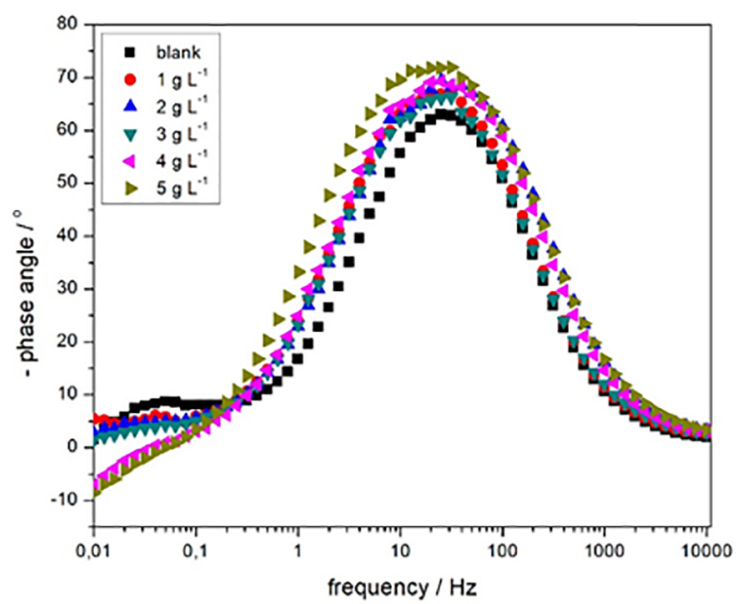

Figure 7. Bode phase angle plots for AISI 304 stainless steel in $\mathrm{H}_{2} \mathrm{SO}_{4}$ in presence and absence of AEAW.

This indicates that the AEAW adsorbs onto the metallic surface, reducing the available area to the occurrence of corrosion reactions and changing the anodic reaction mechanim ${ }^{17}$. The IE values calculated using $R_{c t}$ values showed an increase of IE with the extract concentration varying from 44.4 to $71.1 \%$ for the extract concentration from 1 to $5 \mathrm{~g} \mathrm{~L}^{-1}$. These values are in accordance with those one presented in Table 1, corroborating the adsorption dependence on the applied potential. Both gravimetric essays and electrochemical impedance were obtained at open circuit potential.

Table 6. Electrochemical parameters for AISI 304 stainless steel in $\mathrm{H}_{2} \mathrm{SO}_{4}$ obtained by EIS.

\begin{tabular}{ccccc}
\hline [AEAW] $/ \mathrm{g} \mathrm{L}^{-1}$ & $\mathrm{R}_{\mathrm{ct}} / \Omega \mathrm{cm}^{2}$ & $\mathrm{f}_{\max } / \mathrm{Hz}$ & $\mathrm{C}_{\mathrm{dl}} / \mu \mathrm{F} \mathrm{cm} \mathrm{cm}^{-2}$ & $\mathrm{IE}(\%)$ \\
\hline 0 & 165 & 3.98 & 242 & - \\
1 & 297 & 2.51 & 229 & 44.4 \\
2 & 332 & 2.51 & 191 & 50.3 \\
3 & 384 & 1.99 & 208 & 57.0 \\
4 & 364 & 1.99 & 220 & 54.7 \\
5 & 571 & 1.58 & 176 & 71.1 \\
\hline
\end{tabular}


Figure 7 shows that the stainless steel sample immersed in $\mathrm{H}_{2} \mathrm{SO}_{4}$ presented a single time constant in the 10000-1 $\mathrm{Hz}$ region associated with the charge transfer process. This behavior remains the same with the addition of the AEAW. Higher phase angles were obtained for the samples containing the AEAW, suggesting that the film formed in these conditions is more protective.

\section{Conclusions}

The extract acted as an inhibitor of the AISI 304 stainless steel corrosion in $1.5 \mathrm{~mol} \mathrm{~L}^{-1} \mathrm{H}_{2} \mathrm{SO}_{4}$, by adsorption process, as the gravimetric and electrochemical results indicated.

The adsorption process obeyed a Temkin isotherm model, with repulsive forces between the extract molecules on the adsorption process.

The AEAW acted increasing the apparent activation energy of the corrosion reactions, in a physical adsorption mechanism. The extract showed to be a mixed type inhibitor at polarization conditions with great inhibition efficiency.

\section{Acknowledgments}

This work was carried out with the support of Coordenação de Aperfeiçoamento de Pessoal de Nível Superior - Brazil (CAPES). Financing code 001. The authors also thank CNPq, FINEP and Fundação Araucária for financial support.

\section{References}

1. Sharma MK, Arora P, Kumar S, Mathur SP, Ratnani R. Inhibitive effect of Prosopis cineraria on mild steel in acidic media Inhibitive effect of Prosopis cineraria on mild steel in acidic media. Corrosion Engineering, Science and Technology. 2016;43(3):213-218.

2. Li X, Deng $\mathrm{S}, \mathrm{Fu} \mathrm{H}$. Inhibition of the corrosion of steel in $\mathrm{HCl}$, $\mathrm{H}_{2} \mathrm{SO}_{4}$ solutions by bamboo leaf extract. Corrosion Science. 2012;62:163-175.

3. Souza FS, Spinelli A. Caffeic acid as a green corrosion inhibitor for mild steel. Corrosion Science. 2009;51(3):642-649.

4. Felipe MBMC, Maciel MAM, Medeiros SRB, Silva DR. Aspectos gerais sobre corrosão e inibidores vegetais. Revista Virtual de Química. 2013;5(4):746-759.

5. Rocha JC, Gomes JACP, D'Elia E. Corrosion inhibition of carbon steel in hydrochloric acid solution by fruit peel aqueous extracts. Corrosion Science. 2010;52(7):2341-2348.

6. El-Etre AY. Inhibition of acid corrosion of carbon steel using aqueous extract of olive leaves. Journal of Colloid and Interface Science. 2007;314(2):578-583.

7. Assis B, Meira FO, Pina VGSS, Andrade GF, Cotrim BA, Resende GO, et al. Inhibitory Effect of Piper Nigrum L. Extract on the Corrosion of Mild Steel in Acidic Media. Revista Virtual de Quimica. 2015;7(5):1830-1840.
8. Saleh RM, Ismail AA, El Hosary AA. Corrosion inhibition by naturally occurring substances-IX. The effect of the aqueous extracts of some seeds, leaves, fruits and fruit-peels on the corrosion of Al in NaOH. Corrosion Science. 1983;23(11):1239-1241.

9. Zucchi F, Omar IH. Plant extracts as corrosion inhibitors of mild steel in HCl solutions. Surface Technology. 1985;24(4):391-399.

10. El-Etre AY. Khillah extract as inhibitor for acid corrosion of SX 316 steel. Applied Surface Science. 2006;252(24):8521-8525.

11. Abdel-Gaber AM, Abd-El-Nabey BA, Sidahmed IM, El-Zayady AM, Saadawy M. Inhibitive action of some plant extracts on the corrosion of steel in acidic media. Corrosion Science. 2006;48(9):2765-2779.

12. Torres VV, Amado RS, Sá CF, Fernandez TL, Riehl CAS, Torres $\mathrm{AG}$, et al. Inhibitory action of aqueous coffee ground extracts on the corrosion of carbon steel in $\mathrm{HCl}$ solution. Corrosion Science. 2011;53(7):2385-2392.

13. Noor EA. The impact of some factors on the inhibitory action of Radish seeds aqueous extract for mild steel corrosion in $1 \mathrm{M} \mathrm{H}_{2} \mathrm{SO}_{4}$ solution. Materials Chemistry and Physics. 2011;131(1-2):160-169.

14. Pereira SSAA, Pêgas MM, Fernández TL, Magalhães M, Schöntag TG, Lago DC, et al. Inhibitory action of aqueous garlic peel extract on the corrosion of carbon steel in $\mathrm{HCl}$ solution. Corrosion Science. 2012;65:360-366.

15. Soltani N, Tavakkoli N, Khayatkashani M, Jalali MR, Mosavizade A. Green approach to corrosion inhibition of 304 stainless steel in hydrochloric acid solution by the extract of Salvia officinalis leaves. Corrosion Science. 2012;62:122-135.

16. Teixeira VM, Santos ÉC, Rezende MJC, D’Elia E. Estudo da Ação Inibidora do Extrato de Camellia sinensis na Corrosão do Aço-carbono $1020 \mathrm{em} \mathrm{HCl} 1 \mathrm{~mol} \mathrm{~L}^{-1}$. Revista Virtual de Química. 2015;7(5):1780-1794.

17. Matos LAC, Taborda MC, Alves GJT, Cunha MT, Banczek EP, Oliveira MF, et al. Application of an acid extract of barley agro-industrial waste as a corrosion inhibitor for stainless steel AISI 304 in $\mathrm{H}_{2} \mathrm{SO}_{4}$. International Journal of Electrochemical Science. 2018;13:1577-1593.

18. Rodrigues PRP, Andrade AHP, Agostinho SML. Benzotriazole as corrosion inhibitor for type 304 stainless steel in water-ethanol media containing $2 \mathrm{M} \mathrm{H}_{2} \mathrm{SO}_{4}$. British Corrosion Journal. 1998;33(3):211-213.

19. Rodrigues PRP. O benzotriazol como inibidor de corrosão para ferro e ligas ferrosas em meios de ácido sulfúrico [thesis]. São Paulo (SP): Universidade de São Paulo; 1997.

20. Bruckmoser K, Resch K, Kisslinger T, Lucyshyn T. Measurement of interdiffusion in polymeric materials by applying Raman spectroscopy. Polymer Testing. 2015;46:122-133.

21. Oguzie EE. Evaluation of the inhibitive effect of some plant extracts on the acid corrosion of mild steel. Corrosion Science. 2008;50(11):2993-2998.

22. Oguzie EE, Enenebeaku CK, Akalezi CO, Okoro SC, Ayuk AA, Ejike EN. Adsorption and corrosion-inhibiting effect of Dacryodis edulis extract on low-carbon-steel corrosion in acidic media. Journal of Colloid and Interface Science. 2010;349(1):283-292. 
23. Rosa CF, Beta T, Fulcher G, Francisco A. Efeito do perolamento na atividade antioxidante e composição fenólica da cevada. Alimentos e Nutrição. 2007;18(1):69-75.

24. Fouda AS, Ellithy AS. Inhibition effect of 4-phenylthiazole derivatives on corrosion of $304 \mathrm{~L}$ stainless steel in $\mathrm{HCl}$ solution. Corrosion Science. 2009;51(4):868-875.

25. Torres VV, Cabral GB, Silva ACG, Ferreira KCR, D’Elia E. Ação inibidora de extratos da semente do mamão papaia na corrosão do aço-carbono $1020 \mathrm{em} \mathrm{HCl} 1 \mathrm{~mol} \mathrm{~L}^{-1}$. Química Nova. 2016;39(4):423-430.

26. Abiola OK, Aliyu AOC, Phillips AA, Ogunsipe AO. The effects of Phyllanthus amarus extract on corrosion and kinetics of corrosion process of aluminum in $\mathrm{HCl}$ solution. Journal of Materials and Environmental Science. 2013;4(3):370-373.

27. Souza FS, Gonçalves RS, Spinelli A. Assessment of Caffeine Adsorption onto Mild Steel Surface as an Eco-Friendly Corrosion Inhibitor. Journal of the Brazilian Chemical Society. 2014;25(1):81-90.

28. Almeida CAP. Caracterização do lutito barro branco e avaliação de sua capacidade como adsorvente de corantes usando o azul de metileno como modelo [thesis]. Florianópolis (SC): Universidade Federal de Santa Catarina; 2005.
29. Barros I, Moscoso HZL, Custódio D, Veiga V, Bastos I. Aniba canelilla as Corrosion Inhibitor of Carbon Steel. Revista Virtual de Química. 2015;7(5):1743-1755.

30. Chaubey N, Savita, Singh VK, Quraishi MA. Corrosion inhibition performance of different bark extracts on aluminium in alkaline solution. Journal of the Association of Arab Universities for Basic and Applied Sciences. 2017;22:38-44.

31. Gallina AL. Produção de gás hidrogênio utilizando glicerina e eletrodos metálicos de baixo custo [thesis]. Guarapuava (PR): Universidade Estadual do Centro Oeste; 2014.

32. Rodrigues PRP. Ação do Benzotriazol como Inibidor de Corrosão para o Aço Inoxidável Austenítico 304 em meio de $\mathrm{H}_{2} \mathrm{SO}_{4} 2 \mathrm{M}$ Empregando como solventes água e mistura água - etanol [dissertation]. São Paulo (SP): Universidade de São Paulo; 1993.

33. Abdallah M. Corrosion behaviour of 304 stainless steel in sulphuric acid solutions and its inhibition by some substituted pyrazolones. Materials Chemistry and Physics. 2003;82(3):786-92.

34. Fuchs-Godec R, Zerjav G. Corrosion resistance of high-levelhydrophobic layers in combination with Vitamin $\mathrm{E}-(\alpha$-tocopherol) as green inhibitor. Corrosion Science. 2015;97:7-16. 